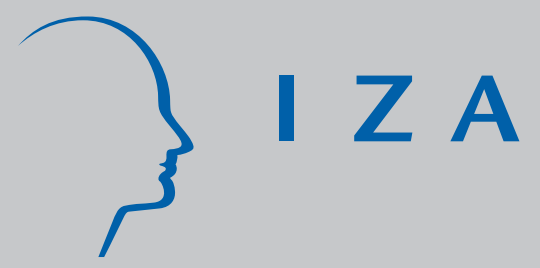

IZA DP No. 3465

Cost and Benefit of Apprenticeship Training: A Comparison of Germany and Switzerland

Regina Dionisius

Samuel Muehlemann Harald Pfeifer

Günter Walden

April 2008
Felix Wenzelmann

Stefan C. Wolter 


\section{Cost and Benefit of Apprenticeship Training: A Comparison of Germany and Switzerland}

\author{
Regina Dionisius \\ $B I B B$ \\ Samuel Muehlemann \\ University of Berne and IZA
}

Harald Pfeifer

$B I B B$

\author{
Günter Walden
}

$B I B B$

Felix Wenzelmann

$B I B B$

Stefan C. Wolter

University of Berne, CESifo and IZA

\section{Discussion Paper No. 3465 \\ April 2008}

IZA

P.O. Box 7240

53072 Bonn

Germany

Phone: +49-228-3894-0

Fax: +49-228-3894-180

E-mail: iza@iza.org

Any opinions expressed here are those of the author(s) and not those of IZA. Research published in this series may include views on policy, but the institute itself takes no institutional policy positions.

The Institute for the Study of Labor (IZA) in Bonn is a local and virtual international research center and a place of communication between science, politics and business. IZA is an independent nonprofit organization supported by Deutsche Post World Net. The center is associated with the University of Bonn and offers a stimulating research environment through its international network, workshops and conferences, data service, project support, research visits and doctoral program. IZA engages in (i) original and internationally competitive research in all fields of labor economics, (ii) development of policy concepts, and (iii) dissemination of research results and concepts to the interested public.

IZA Discussion Papers often represent preliminary work and are circulated to encourage discussion. Citation of such a paper should account for its provisional character. A revised version may be available directly from the author. 


\section{ABSTRACT}

\section{Cost and Benefit of Apprenticeship Training: A Comparison of Germany and Switzerland}

For the first time it has been made possible to merge a German and a Swiss firm-level data set that include detailed information about costs and benefits of apprenticeship training. Previous analyses based only on aggregate data showed that the net costs of training apprentices are substantial in Germany, whereas apprenticeship training is on average profitable during the training period for firms in Switzerland, even though the two training systems are rather similar. This paper analyzes the reasons for these differences with matching methods. We simulate the impact of changes in certain parameters such as wages, apprenticeship system-related factors and allocation of tasks to apprentices on the costbenefit ratio using the counterfactual values of the other country. The results show that most of the difference in the net costs of training between the two countries can be explained by a higher share of productive tasks allocated to apprentices in Switzerland and the differences in relative wages.

JEL Classification: J24, J31, J44

Keywords: apprenticeship training, cost and benefit analysis

Corresponding author:

Samuel Muehlemann

University of Berne

Department of Economics

Schanzeneckstrasse 1

P.O. Box 8573

$\mathrm{CH}-3001$ Berne

Switzerland

E-mail: samuel.muehlemann@vwi.unibe.ch

\footnotetext{
* The authors would like to thank Ursula Beicht, Hermann Herget and Jürg Schweri for their work in conducting the cost-benefit-surveys that constitute the data base for this paper. The Swiss survey was financed by the Commission for Technology and Innovation (CTI) with the help of the Swiss Federal Statistical Office (BFS).
} 


\section{Introduction}

Over the past decades, a number of surveys have been conducted in Germany and Switzerland that analyzed the costs and benefits of apprenticeship training from the firm's perspective. ${ }^{1}$ Recent empirical research for Switzerland showed that the training behavior of a firm is influenced significantly by the net costs of an apprenticeship program, either directly (see Wolter et al., 2006; Muehlemann et al., 2007) or indirectly by factors related to the net costs of training (see Muehlemann and Wolter, 2007a,b). Walden (2007) in a replication of the Swiss analysis concludes that costs and benefits also play a significant role in the company training behavior in Germany, although the impact of the net costs is smaller compared to Switzerland. Nevertheless, these economic factors play an important role in apprenticeship training, even though economists have neglected the analysis of the dual apprenticeship system for quite some time.

In this paper, we make a comparison of the cost-benefit situation of firms that train apprentices in two countries where the dual vocational education and training (VET) system is very important and has a long tradition: Germany and Switzerland. ${ }^{2}$ Despite the institutional and structural similarities of the dual VET systems, the cost-benefit situation for firms that train apprentices is very different if we compare the two countries at the aggregate level. Apprenticeship training on average is profitable in Switzerland already during the training period, whereas German firms bear substantial net costs of training apprentices.

This empirical finding is the starting point of our analysis. So far, it was argued that structural differences between the two countries, such as different training professions, a different industry structure, firm characteristics like firm size or different relative wages of apprentices and skilled workers

\footnotetext{
${ }^{1}$ See Noll et al. (1983), Von Bardeleben et al. (1991, 1995, 1997) and Beicht et al. (2004) for Germany or Schweri et al. (2003) and Muehlemann et al. (2007) for Switzerland. Wolter (2008) gives an overview of the development and the use of cost-benefit analyzes for apprenticeship training since the survey of the so-called "Edding-commission" in 1974 (Sachverständigenkommission Kosten und Finanzierung der beruflichen Bildung, 1974); see also Section 2.1.

${ }^{2}$ In both countries, more than half of a cohort of school leavers enrolls in a dual apprenticeship program.
} 
could account for these differences. Furthermore, Germany and Switzerland also differ by a large degree with regards to labor market regulations and institutions. In Germany, unions have a much stronger influence and it is more difficult to lay off workers compared to Switzerland. As well, German work councils can directly influence the firm's strategy at the micro level, which includes the training of young workers. The studies by Acemoglu and Pischke (1998, 1999a,b) and Franz and Soskice (1995) highlight the importance of labor market institutions and frictions with regards to the firm's decision to provide training. The contribution of this paper to the literature is that for the first time we can analyze the cost-benefit ratio of apprenticeship training of two countries that have a similar VET system, but differ substantially with respect to labor market regulations and institutions. ${ }^{3}$

Our results show that the difference in net costs of training cannot solely be attributed to structural differences of the two countries. Using matching methods, we find that the allocation of tasks to apprentices at the workplace is an important determinant of the difference in the net costs of training. The effect is even more pronounced if the wage-level of skilled workers is high. As a result, the benefits of training, i.e. the value of the productive work of apprentices, is much higher in Switzerland than in Germany and constitutes the main source for the difference in the cost-benefit ratio between the two countries.

The paper is organized as follows: First, we discuss the costs-benefit surveys of apprenticeship training and provide descriptive statistics. The following section describes the econometric modeling and the estimation strategy. Section 4 presents the empirical results. Section 5 discusses the implications of our findings. Section 6 concludes.

\footnotetext{
${ }^{3}$ In the OECD Employment Outlook (OECD, 2004), the value of the overall index for employment protection legislation in the year 2003 is 2.5 for Germany and 1.6 for Switzerland. As a comparison, the United States have a value of 0.7, the United Kingdom 1.1, whereas Sweden and Norway have a value of 2.6 and France a value of 2.9. Germany is ranked in the top third of the countries with highest index of employment protection legislation, whereas Switzerland is situated in the lowest quartile.
} 


\section{Cost-benefit-surveys and data}

In this section, we introduce the concepts and the methodology of the costbenefit-surveys of apprenticeship training and present descriptive results for Germany and Switzerland.

\subsection{Cost-benefit-surveys of apprenticeship training}

The concepts of cost-benefit-surveys of apprenticeship training have been developed by the "Expert Commission on Costs and Financing of Vocational Education and Training" in 1974, which is also known as the "EddingCommission". In our analysis, we use two surveys that were conducted simultaneously in Germany (see Beicht et al. 2004) and Switzerland (Schweri et al. 2003), both with the same reference year (2000).

From a methodological point of view, the results of the two surveys are comparable, even though there are some differences with regards to how they were conducted. ${ }^{4}$ Nevertheless, most questions have been posed in exactly the same way, as the Swiss questionnaire was based on the German questionnaire. $^{5}$

However, even though the questions are mainly identical, Beicht et al. (2004) applied two different methods to calculate costs and benefits. The main difference is that first method does not include expenses for part-time training personnel, whereas the second method does. To maximize the comparability of the two surveys, the German costs and benefits of training have been re-estimated with the model used in the Swiss survey, which is very similar to the second method of the German survey.

\footnotetext{
${ }^{4}$ In Germany, the survey was conducted by personal interviews, while Swiss firms were sent written questionnaires and have subsequently been contacted by phone for remaining questions.

${ }^{5}$ The wording of some questions was slightly different, e.g. Swiss firms were asked about the share productive and non-productive tasks of their apprentices at the workplace, whereas German firms could differentiate further between three sub-categories for nonproductive tasks. While such differences could result in a somewhat different responsebehavior of firms, it should not affect the comparability.
} 


\subsection{The cost-benefit model}

The costs of apprenticeship training mainly consist of the wages of apprentices $w_{a}$ and the cost for the training personnel $w_{t}$. In addition, there are expenses for material, infrastructure, external courses, costs for hiring and administration of apprentices and other, denoted by $X .{ }^{6}$ This yields the following costs for firm i:

$$
c_{i}=w_{a i}+w_{t i}+X_{i}
$$

where $c_{i}$ denotes the costs for an average year of the training period per apprentice. The calculation of training costs suggests that they are mainly determined by wages. Hence, differences in training costs between firms are primarily due to variables that influence either the wage of apprentices or the wage of training personnel. The calculation of the benefits $b$ is based on the type of work the apprentices perform. An apprentice spends a fraction $\alpha$ of his productive working time $h$ performing activities that would otherwise be carried out by unskilled workers. The remaining time $(1-\alpha) h$, the apprentice performs skilled work. In the first case, we can assume that the apprentice's performance has the same value as that of an unskilled worker, i.e. the wage of an unskilled worker $w_{u}$. However, the value of the apprentice's performance for an hour of skilled work is less than the hourly wage $w_{s}$ of a fully trained skilled worker. The values of the apprentice's work has to be adjusted by a relative productivity measure $\gamma$, since apprentices are not yet as efficient as a skilled worker with a vocational degree. Hence, the benefits of training to firm i are given by

$$
b_{i}=\left[\alpha w_{u i}+(1-\alpha) \gamma w_{s i}\right] h
$$

where $b_{i}$ denotes the benefits for an average year of training per apprentice. The net costs $C$ of training an apprentice are the difference between the $\operatorname{costs} c$ and the benefits $b$. As a result, the net costs of an average year of training per apprentice for firm i are given by

$$
C_{i}=c_{i}-b_{i}
$$

\footnotetext{
${ }^{6}$ For details on the cost-benefit model see Schweri et al. 2003.
} 


\subsection{Data and sample selection}

The data in this paper are from two firm-level surveys on the costs and benefits of apprenticeship training. The first survey was conducted in Germany by the Federal Institute for Vocational Education and Training in Bonn (Beicht et al. 2004), whereas the second study has been carried out by the Centre for Research in Economics of Education at the University of Berne (see Schweri et al. 2003). All results presented in this article are weighted by sampling weights that account for the stratified sampling. ${ }^{7}$ The analysis focuses only on apprenticeship programs that last three years, since programs exceeding three years last 3.5 years in Germany, but four years in Switzerland, which would make a comparison less meaningful. The sample used for the analysis consists of 1825 German and 1471 Swiss firms.

\subsection{Descriptive statistics}

The costs-benefit ratio of apprenticeship training from the firm's perspective between Germany and Switzerland differs significantly (see Tables A.1 and A.2 in the Appendix for descriptive statistics). The average costs of training $c$ amount to $15,537 €$ in Germany. The corresponding value for Switzerland is $18,131 €{ }^{8}$ This results in $\Delta c$ between Germany and Switzerland of 2595 $€$ per year, which amounts to $7785 €$ in total for a three-year training program. This difference is substantial, but relatively small compared to the difference in the benefit of training. The value of the productive contribution of apprentices is much higher in Switzerland, where the average benefit $b$ amounts to $19,044 €$. In Germany, $b$ is on average $8008 €$ per year and per apprentice. ${ }^{9}$ Hence, apprenticeship training in Germany results in net costs

\footnotetext{
${ }^{7}$ For the calculation of the weights for the Swiss survey see Renfer (2002) and Potterat (2003). For documentation on the calculation of the weights for the German survey see Schröder et al. (2001).

${ }^{8}$ To convert the results of the Swiss survey (which are reported in CHF) into $€$, we used the exchange rate on September 1st, $2000(1 \mathrm{CHF}=0.64687 €)$.

${ }^{9}$ In two recent papers, Zwick (2007) and Mohrenweiser and Zwick (2008) dispute the finding that German firms incur high net costs of training. On the basis of firm-level panel data they estimate the impact of changes in the share of apprentices on firm profit. They do not find an impact on average, and in the sectorial analysis they only find a (negative) impact for manufacturing occupations. They conclude from this that only a minority of German firms has to bear net costs when training apprentices. Without going
} 
$C$ of $7528 €$ p.a., whereas in Switzerland, firms can generate an average net benefit of $913 €$. As a result, $\Delta C$ between Germany and Switzerland for a three year apprenticeship program equals $25,323 €$. Figure A.1 shows a histogram of the net costs for Germany and Switzerland. It can be seen that the distributions of net costs are fairly similar. However, it can be observed that the distribution of the net costs for Germany is shifted to the right, i.e. net costs are higher compared to Switzerland. This large difference in net costs is the starting point of our analysis. We first focus on the components of the net costs, to see whether they already show large differences in a bivariate analysis. The main components of the $\operatorname{costs} c$ are wages for training personnel $w_{t}$ and wages of apprentices $w_{a}$. The average wage for a management position is $46 \%$ higher in Switzerland, whereas the wage for full-time training personnel is $24 \%$ higher compared to Germany. Wages of skilled workers (administrative, technical/social, crafts) exceed the Germany values by $60 \%$, $53 \%$ and $71 \%$. Last, the monthly wage of a worker without a vocational degree is $59 \%$ higher in Switzerland compared to Germany. ${ }^{10}$ In contrast to the wage level for workers, the wage costs for apprentices $w_{a}$ are on average higher in Germany than in Switzerland. For the first and the second year German apprentices wages are higher $\left.\left(\Delta w_{a 1}=1344 €\right), \Delta w_{a 2}=456 €\right)$, but lower in the third year of the training program $\left(\Delta w_{a 3}=-981 €\right)$.

Further differences can be attributed to the number of days that apprentices are required to spend in a vocational school. The average difference between Germany and Switzerland amounts to 15 days in the first, 10 days in the second and 8 days in the third year of training. This is the main reason why Swiss apprentices spend more days per year at the workplace within the training firm. In addition, German apprentices also spend more days in internal and external courses and internships in other establishments. As

into details, we do not think that the relationship between shares of apprentices and firm profit reveals anything about the net costs of training. Besides, it can be shown with firm-level data that even if firms within a particular group of professions do not incur net costs on average, it does not even imply that the majority of firms does not have to bear net costs. In addition, we find that the large difference in net costs between Germany and Switzerland persists also within single professions, which contradicts the assumptions made in Mohrenweiser and Zwick (2008).

${ }^{10}$ On the other hand, non-wage labor costs are higher in Germany (37.3\% of the wage on average) than in Switzerland (23\% of the wage on average) 
a result, Swiss apprentices spend more time at the workplace compared to German apprentices $(+23$ days in the first year, +18 days in the second year and +13 days in the third year).

Independent of the time apprentices spend in firms, major differences in terms of net costs of training may occur due to the type of work and training within the firm. Firms have a large degree of freedom with respect to the allocation of tasks to apprentices during the time they spend at the workplace. They can perform productive activities (either tasks usually performed by skilled workers or tasks usually performed by unskilled workers, i.e. workers without a vocational degree), or activities that have no direct value to the firm (e.g. time for practicing or instruction time at the workplace).

The differences between Germany and Switzerland with respect to these parameters are substantial. The share of the time allocated to non-productive activities to German apprentices exceed the corresponding values for Swiss apprentices by $36 \%$-points in the first year, $28 \%$-points in the second year and $18 \%$-points in the third year. Over a whole apprenticeship period, Swiss apprentices spend 468 days at the workplace and spend $83 \%$ of this time with productive tasks, while German apprentices spend a total of 415 days at the workplace and spend $57 \%$ of their time with productive tasks.

However, the respective shares of qualified and unqualified productive activities do not differ much between the two countries. This also means that the higher share of productive activities of Swiss apprentices is not due to a higher share of unqualified labor compared to Germany. In line with these findings, the relative productivity of apprentices performing skilled work increases by the same amount over time; i.e. from $37 \%$ in the first year to $75 \%$ in the final year of the apprenticeship program in Switzerland and from $30 \%$ to $68 \%$ respectively in Germany. This is also an indication that the two apprenticeship training systems lead to comparable outcomes, in the sense that the relative performance of the apprentices compared to skilled workers in the final year of the training program is almost the same in both countries (see also descriptive results in the Appendix).

Although the differences in some of the parameters of the costs and benefits are substantial, we start by testing how much of the aggregate difference in the net costs between the two countries can be explained by structural dif- 
ferences alone. To do so, we run a series of OLS-regressions (see Table A.3). The results show that the difference between Germany and Switzerland does not decrease if control variables for firm size (model 2), industry (model 3), job categories (model 4) and indicators for firms having a company training center and full-time training personnel (model 5) are included.

\section{Empirical modeling}

The results in Table A.3 show that the large differences in the net costs of training between Germany and Switzerland cannot be explained by structural variables such as industry, firm size or training profession. However, since the net costs are the result of a constructed cost-benefit model where all parameters are known, it must be possible to explain these differences. Unfortunately, it is not possible to simply apply an OLS-regression and include these parameters as independent variables, since they all enter the net costs by construction. Instead of trying to directly estimate the effects of these parameters on the net costs, we apply matching-models analogous to the treatment effects literature. ${ }^{11}$ Instead of estimating the effects of e.g. an active labor market program of unemployment, we estimate the effect of hypothetically moving a firm step by step to the other country by changing the parameters in the net cost equation that showed the largest differences in the descriptive analysis. After doing this, we re-estimate the cost-benefit model for each firm and as a result we obtain a new estimate of the net costs of training apprentices. This procedure enables us to determine how much of the difference between Germany and Switzerland can be explained by these parameters.

Let the observed outcome be denoted by $Y_{i}$ :

$$
Y_{i}=Y_{i}\left(D_{i}\right)=\left\{\begin{array}{lll}
Y_{i}(0) & \text { if } & D_{i}=0 \\
Y_{i}(1) & \text { if } & D_{i}=1
\end{array}\right.
$$

where $D_{i}$, for $D_{i} \in 0,1$ is the treatment indicator, i.e. whether observation $i$ is a firm located in Germany $\left(D_{i}=1\right)$ or Switzerland $\left(D_{i}=0\right)$. Formally, we are interested in the average treatment effect on the treated (ATT), which

\footnotetext{
${ }^{11}$ For seminal work on matching methods see among others Rubin (1974) and Rosenbaum and Rubin (1983)
} 
can be interpreted as if a German firm faces the environment of a Swiss firm, such that

$$
A T T_{i}=E\left[Y_{i}(1)-Y_{i}(0) \mid D_{i}=1\right]
$$

We are also interested in the average treatment effect on the controls (ATC), which can be interpreted in a way that a Swiss firm faces the environment of a German firm, such that

$$
A T C_{i}=E\left[Y_{i}(1)-Y_{i}(0) \mid D_{i}=0\right]
$$

If an individual or a firm could self-select in a treatment group, then the matching estimator would be biased. In our case the treatment cannot be interpreted as random, but the unconfoundedness assumption (see Rosenbaum and Rubin, 1983) is assumed to hold. ${ }^{12}$ Hence, the assumption that the treatment $D_{i}$ is independent of the outcome variables $(Y(0), Y(1)$ ), i.e. the parameters of the net costs of apprenticeship training, still holds.

We apply a simple matching estimator (see Abadie et al. (2004)) to estimate the counterfactual outcome, i.e. the value that is not observed for firm $i$. While the observed outcome is its own estimate, the unobserved outcome is estimated by averaging the outcomes of the most similar firms in the other country, such that

$$
\hat{Y}_{i}(0)=\left\{\begin{array}{cl}
Y_{i} & \text { if } D_{i}=0 \\
\frac{1}{\# \mathcal{J}_{M}(i)} \sum_{l \in \mathcal{J}_{M(i)}} Y_{l} & \text { if } D_{i}=1
\end{array}\right.
$$

and

$$
\hat{Y}_{i}(1)=\left\{\begin{array}{cl}
\frac{1}{\# \mathcal{J}_{M}(i)} \sum_{l \in \mathcal{J}_{M(i)}} Y_{l} & \text { if } D_{i}=0 \\
Y_{i} & \text { if } D_{i}=1
\end{array}\right.
$$

where $\mathcal{J}_{M}(i)$ denotes the set of indices for the matches for a firm $i$ (for more details see Abadie et al. 2004).

\footnotetext{
${ }^{12}$ The matching estimates would be biased if firms had chosen their location based unobserved factors that are related to parameters of the net costs of apprenticeship training. Since apprenticeship training is usually not the core business of a firm, we assume that firms base their location decision on other factors unrelated to the costs of apprenticeship training.
} 
The estimation strategy is as follows:

1. In a first step, we estimate the treatment effects on a number of variables that are relevant to the net costs of apprenticeship training. The descriptive statistics (see Section 2.4) show that the main differences between Germany and Switzerland can be attributed to the following parameters:

- Wages of apprentices and skilled workers and non-wage labor costs

- Parameters related to the VET system and institutions that affect the number of days where apprentices are at the workplace of the training firm: the number of days that apprentices spend in vocational school, external and internal courses, vacation and sick days as well as internships in other firms.

- The allocation of tasks to apprentices at the workplace, i.e. the share of tasks that have direct value to the firm and the share of tasks that do not have a direct value to the firm.

The matching is conducted using a set of independent variables including firm size, industry, job categories and two binary variables indicating whether the firm has a separate company training center and whether the firm employs full-time training personnel.

2. Having obtained counterfactual values for the parameters of interest, both for German firms hypothetically facing the environment of a Swiss firm $\left(\hat{Y}_{i}(1)\right.$ if $\left.D_{i}=0\right)$ and for Swiss firms hypothetically facing the environment of a German firm $\left(\hat{Y}_{i}(0)\right.$ if $\left.D_{i}=1\right)$, we can now re-estimate the underlying cost-benefit model (see Section 2.2) at the firm-level, while all other parameters of the model remain unchanged. As a result, we get a new estimate for the costs and benefits of apprenticeship training.

\section{Results}

In this section, we present the results of our simulations based on the matching-models. The first subsection presents the results for German firms 
receiving treatment for a Swiss firm environment, whereas the following subsection presents the opposite case, i.e. Swiss firms receiving treatment for a German firm environment.

\subsection{Treatment effects on German firms}

Instead of using the original parameter values of interest $E\left[Y_{i}(1) \mid D_{i}=1\right]$ to calculate the costs and benefits, we now use the estimates of the parameter values $E\left[Y_{i}(1) \mid D_{i}=0\right]$ to re-calculate the new cost-benefit situation.

We will proceed in two steps. We first estimate all treatment effects individually to get a notion of the relative magnitude of the individual parameters and in a second step we will simultaneously estimate all treatment effects together.

The first parameters to change are wages. German firms receive a treatment for wages of skilled workers and apprentices as well as non-wage labor costs, such that they match the situation of a comparable Swiss firm. The average treatment effects on the treated $A T T_{i}=E\left[Y_{i}(1)-Y_{i}(0) \mid D_{i}=1\right]$ are presented in Table A.6. Average monthly wages for skilled workers are about 1,300€ higher in Switzerland; hence the costs of training increases because the time for training personnel becomes more costly for a German firm facing Swiss wages. However, the effects of higher wages on the net costs of training are ambiguous, since a higher wage-level also increases the value of productive work that is carried out by apprentices. The results show that the costs of apprenticeship training increase by $2214 €$ p.a. and per apprentice (see Table 1), whereas average benefits increase by about $3340 €$. Hence, the overall effect of higher wage costs is negative and leads to a decrease in the net costs of training by $1126 €$.

The second group of parameters that get treated are related to regulations of the VET-systems and institutions, i.e. the number of days that apprentices are away from the firm because of vocational school, external and internal courses, vacation and sick days. The average treatment effects on the treated are presented in Table A.7. The effects of these parameters on the net costs for a firm are smaller compared to the wage effects. The costs of training increase by $326 €$ (the apprentice spends more time at the firm now, which increases training costs) and the benefits increase by $869 €$. This leads to a 
decrease in net costs of training by $534 €$ for a German firm.

Table 1: Effects of treatment on costs and benefits for German firms

\begin{tabular}{lrrr}
\hline Treatment & $\Delta$ Costs & $\Delta$ Benefits & $\Delta$ Net costs \\
Wages & 2214 & 3340 & -1126 \\
VET-system & 326 & 869 & -543 \\
Allocation of tasks to apprentices & -69 & 2865 & -2934 \\
\hline
\end{tabular}

Change in $€$ compared to original values

In a third step, German firms receive treatment with respect to the allocation of tasks to apprentices at the workplace. As shown in the descriptive statistics (see Section 2.4), there are large differences between the two countries. This has obviously a sizeable impact on the net costs of training apprentices. The treatment effects on the treated with respect to the share of non-productive work are large and highly significant (see Table A.8). Having obtained the counterfactual values, we re-estimate the cost-benefit model again and find that due to a now increased productive contribution of the apprentices the net costs of training decrease by $2934 €$ p.a.. The effects described above are economically substantial and add up to $4603 €$. This explains $55 \%$ of the initial difference in net costs between Germany and Switzerland.

However, it can be suspected that changes in some parameters affect other parameters as well; e.g. an increased share of tasks to apprentices that have a direct productive value to the firms is expected to result in a larger benefit of training if the wages of skilled workers are high, i.e. an hour of work by an apprentice is then worth more to the firm (ceteris paribus). Similarly, at given wages and a given allocation of tasks, the productive value of apprentices should increase if they spend more days per year at the workplace. Therefore, all parameters of interest (wages, VET-system, allocation of tasks to apprentices) get treated simultaneously and we then re-estimate the cost-benefit model again. If a German firm face Swiss wagelevels, the parameters of the Swiss VET-system and allocate the share of productive and non-productive tasks in a manner that a comparable Swiss firms does, then the net costs of training for a German firm decline by $6594 €$ to $934 €$ p.a. and per apprentice (see Table 2 ). 
Table 2: Costs and benefits after treatment for German firms

\begin{tabular}{lrrr}
\hline Treatment & Costs & Benefits & Net costs \\
None & 15536 & 8008 & 7528 \\
Wages & 17750 & 12148 & 6402 \\
Wages \& VET-system & 18205 & 12679 & 5526 \\
Wages \& VET-system \& Task-allocation & 18066 & 17132 & 934 \\
\hline
\end{tabular}

Absolute values in $€$

Summarizing the results, the main factors that account for the large difference in the net costs of training are the wage-levels of skilled workers and apprentices as well as the time allocation within the firm. The latter is the most important and reduces initial net costs by $61 \%$, given the simulated values for Swiss wages and the Swiss VET-system. It should be noted that the allocation of tasks per se has less of an influence in Germany where $o b$ served wages are lower and apprentices spend less time within the company (see Table 1, it then explains only $35 \%$ of the difference in net costs).

By simulating a change in all three parameters above, $78 \%$ of the initial difference between Germany and Switzerland (which is equal to $8441 €$ ) can be explained by these three groups of parameters. ${ }^{13}$ As can be seen in Table A.4, this difference remains robust and significant in an OLS-Regression that includes structural variables as controls.

\subsection{Treatment effects on Swiss firms}

The procedure outlined above can also be applied to Swiss firms. Instead of using the original parameter values of interest, $E\left[Y_{i}(0) \mid D_{i}=0\right]$ to calculate the costs and benefits, we now use the estimates of the parameter values $E\left[Y_{i}(0) \mid D_{i}=1\right]$ to re-calculate the new cost-benefit situation if a Swiss firm had to face the environment of a German firm with respect to the parameters of interest. In the absence of treatment, training apprentices is profitable

\footnotetext{
${ }^{13}$ It should be noted that the number of training hours as well as the relative productivity of apprentices compared to skilled workers within the training firm have not been affected by the simulation, i.e. they were held constant. Reason being that a change in training hours would result in a change of the relative productivity as well. However, the size of this effect cannot be determined with the data at hand and the net effect of such changes is prima facie not clear.
} 
on average in Switzerland. If a Swiss firm receives treatment with respect to wages, the net costs increase by $3989 €$ (see Table 3 ). The reason for this large effect is that the value of the apprentice's productive work at a lower wage-level decreases by more than the costs of training personnel. In addition, the effect of a change in wages is stronger for Swiss firms than for German firms (as shown above in Table 1) because Swiss apprentices spend more time with productive activities at the workplace. ${ }^{14}$

Table 3: Effects of treatment on costs and benefits for Swiss firms

\begin{tabular}{lrrr}
\hline Treatment & $\Delta$ Costs & $\Delta$ Benefits & $\Delta$ Net costs \\
Wages & -1852 & -5841 & 3989 \\
VET-system & -455 & -2306 & 1851 \\
Allocation of tasks to apprentices & -111 & -5998 & 5887 \\
\hline
\end{tabular}

Change in $€$ compared to original values

The benefits of training apprentices decrease as well if Swiss firms receive treatment for the VET-system. Since apprentices are less available to the firm under the German regime, net costs increase by another $1851 €$. As it is the case for German firms, the allocation of productive and non-productive tasks to the apprentices explains the largest part of the difference in the net costs of training between Germany and Switzerland, i.e. net costs increase by $5887 €$ due to a now lower value of the productive contribution of an apprentice.

Adding up the individual effects, net costs of apprenticeship training increase by $11,727 €$, which is more than the observed difference between the two countries. The reason why the sum of the individual effects is so large is again a simultaneity problem. A change in wages has a larger effect if the share of productive tasks assigned to apprentices is high, and vice versa. Therefore, we re-estimate the cost-benefit model again including the treated parameters of interest simultaneously, as in the previous subsection 4.1. The results show that the expected net costs of apprenticeship training for a Swiss firm facing the environment of a German firm with respect to our parameters of interest amount to $7918 €$ p.a. and per apprentice (Table 4). These

\footnotetext{
${ }^{14}$ See Table A.6 for the average treatment effects on the controls, i.e. $A T C_{i}=E\left[Y_{i}(1)-\right.$ $\left.Y_{i}(0) \mid D_{i}=0\right]$.
} 
simulated net costs exceed the observed average net costs of apprenticeship training in Germany by $390 €$ p.a. and per apprentice. As can be seen in Table A.5, this difference is not significant in an OLS-Regression and remains insignificant if structural variables are included as controls.

Table 4: Costs and benefits after treatment for Swiss firms

\begin{tabular}{lrrr}
\hline Treatment & Costs & Benefits & Net costs \\
None & 18131 & 19044 & -913 \\
Wages & 16279 & 13202 & 3077 \\
Wages \& VET-system & 15971 & 11620 & 4351 \\
Wages \& VET-system \& Task-allocation & 15924 & 8006 & 7918 \\
\hline
\end{tabular}

Absolute values in $€$

The results also imply that the high wage-level of skilled workers in Switzerland is a big incentive for Swiss firms to substitute skilled work by apprentices. A larger share of productive tasks for apprentices would also have a strong impact on the net costs of German firms, but compared to Switzerland, the effect is weaker because of the lower wage-level in Germany.

\section{Discussion}

The findings of the different cost-benefit surveys, both for Germany and Switzerland, have been remarkably stable over time. ${ }^{15}$ As a result, the differences in costs and benefits of apprenticeship training between the two countries have been persistent as well.

For the first time, it is now possible to make use of a merged data set with observations at the firm-level to find an explanation for the large difference in the net costs of training between the two countries. In our analysis we have shown that a large part of this difference can be explained with relatively few parameters of the cost-benefit model. The strongest parameter in this respect is the use of time at the workplace. Swiss apprentices are engaged

\footnotetext{
${ }^{15}$ Von Bardeleben et al. (1995) calculate net costs of $9132 €$ p.a. and per apprentice, whereas the study by Beicht et al. (2004) reports net costs of $8705 €$. For Switzerland, Schweri et al. (2003) find an average net benefit of training of $1353 €$ p.a. and per apprentice, whereas Muehlemann et al. (2007) report an average net benefit of $1787 €$.
} 
more often in productive work compared to their German counterparts. ${ }^{16}$ The open question that still needs to be addressed is why such a large fraction of German firms is willing to incur net costs. Based on our results, firms could adjust some of the relevant parameters that are responsible for part the substantial net costs of training, i.e. the share of productive and non-productive work allocated to apprentices at the workplace. One possible explanation might be found in the differences of the labor market regulations between the two countries. Due to the very high flexibility of the Swiss labor market, most Swiss companies seem to be forced to apply a production-oriented training strategy, whereas labor market regulations allow most German firms to apply an investment-oriented training strategy (see Lindley 1975 for a first discussion of these two strategies). ${ }^{17}$

The mobility of apprentices after graduation is in line with this hypothesis. On average, only $36 \%$ of Swiss apprentices remain within the training firm on year after graduation in the year 2000 (see Wolter and Schweri 2002). In Germany, the corresponding value is more than $50 \%$ (64\% in West Germany and $46 \%$ in East Germany, see Bundesministerium für Bildung und Forschung 2002). This could explain, why there is less pressure on German firms to productively use their apprentices during the training period. But it is more difficult to explain why not more of the German companies go for a double dividend, that is combining net benefits (or at least lower net costs) during training with benefits after training that arise due to the compressed wage structure induced by labor market frictions and regulations (see Acemoglu and Pischke 1998, 1999a,b). A possible reason for the relative reluctance of German firms to substitute skilled or even unskilled work

\footnotetext{
${ }^{16}$ The relatively low amount of productive work of German apprentices had already been highlighted in a comparison of German and French apprentices in the study of Fougère and Schwerdt (2002) using the IAB-establishment panel for Germany and applying a production function approach.

${ }^{17}$ Mohrenweiser and Backes-Gellner (2008) find, on the basis of the IAB establishment panel, that only $18 \%$ of German firms seem to follow a production-oriented (or substitution) strategy. Firms following a substitution strategy are defined by a within-firmretention rate that is lower than 20 percent over three years. Wolter and Schweri (2002) show with Swiss data that following a similar reflection and without directly observing the net costs of training, that more than $70 \%$ of the Swiss firms training apprentices follow a production-oriented strategy. The comparison of the two results is in line with the results of studies that use directly observed net costs of training.
} 
by apprentices might be the strength and behavior of trade unions or work councils. An increased productive contribution of apprentices would make jobs for unskilled or low-skilled workers obsolete, and hence increase unemployment for these worker groups, at least in a static view of the economy. However, net costs of training are - as was shown in recent research (see Section 1) - an important determinant of the firm's decision to train apprentices. Hence, there is a trade-off between unemployment and the number of apprenticeship posts, even if we would adopt a static view of the labor market. ${ }^{18}$

An important matter related to the time use of apprentices at the workplace are the implications on the quality of training. Trade unions, firms and policy makers might advocate against a more substantial involvement of apprentices in productive work. It might be the case that apprentices acquire some competencies only by performing non-productive tasks within the company, such as self-learning. It might well be possible that these competencies are also of importance to the employer, and therefore a firm would be willing to incur substantial net costs of training. However, as was shown in Section 2.4, the relative performance of apprentices at the end of their training period seems to be identical in both countries. Hence, it would be difficult to argue that the benchmarks for comparison are much higher in Germany than in Switzerland. In any case, while the impact of the time and work allocation on the net costs of training is clear, its potential influence on the quality of learning and long-term employment opportunities is open for future research.

\section{Conclusions}

The difference in the net costs of training apprentices from the firm's perspective between Germany and Switzerland amounts to $25,000 €$ for a threeyear training program. Using matching-models, we have shown that this large difference is due to differences in relative wages, different regulations of the vocational education and training systems and, most importantly, to

\footnotetext{
${ }^{18} \mathrm{~A}$ further aspect to be examined in the future are possible differences in the qualifications of apprentices, as these may have an impact on costs and benefits of apprenticeship training.
} 
how a firm allocates tasks to its apprentices, being either activities with a productive value or activities that do not result in a productive value for the firm. Since the difference in the cost-benefit ratio between Germany and Switzerland is to a large degree due to parameters than can be influenced by a firm, it is important to understand why a majority of German firms is willing to bear net costs of training. While our data does not provide a direct answer to this question, we can still draw important implications. Employment protection legislation is much less pronounced in Switzerland than in Germany, hence Swiss firms are forced to train apprentices in a cost-efficient manner. Furthermore, the more pronounced wage differential between apprentices and unskilled and skilled labor in Switzerland is an incentive for Swiss firms to apply a production-oriented instead of an investment-oriented training strategy. However, a further deregulation of the German labor market might force firms to allocate a higher share of productive tasks to their apprentices. 


\section{References}

Abadie, Alberto, David Drukker, Jane Leber Herr, and Guido W. Imbens (2004). Implementing matching estimators for average treatment effects in Stata. Stata Journal 4(3), 290-311.

Acemoglu, Daron and Joern-Steffen Pischke (1998). Why Do Firms Train? Theory and Evidence. Quarterly Journal of Economics 113(1), 79-119.

Acemoglu, Daron and Joern-Steffen Pischke (1999a). Beyond Becker: Training in Imperfect Labour Markets. Economic Journal 109(453), -42.

Acemoglu, Daron and Joern-Steffen Pischke (1999b). The Structure of Wages and Investment in General Training. Journal of Political Economy 107(3), 539-72.

Beicht, Ursula, Günter Walden, and Hermann Herget (2004). Kosten und Nutzen der betreiblichen Berufsausbildung in Deutschland. Bundesinstitut für Berufsbildung. Berichte zur beruflichen Bildung, Heft 264. Bertelsmann: Bielefeld.

Bundesministerium für Bildung und Forschung (2002). Berufsbildungsbericht 2002. Bonn: Bundesministerium für Bildung und Forschung.

Fougère, Denis and Wolfgang Schwerdt (2002). Are Apprentices Productive? Konjunkturpolitik 48(3-4), 317-46.

Franz, Wolfgang and David Soskice (1995). The German Apprenticeship System. In F.Buttler, W.Franz, R.Schettkat, and D.Soskice (Eds.), Institutional Frameworks and Labour Market Performance. Comparative Views on the U.S. and German Economies., pp. 208-34. Routledge, London, New York.

Lindley, Robert M. (1975). The Demand for Apprentice Recruits by the Engineering Industry, 1951-71. Scottish Journal of Political Economy 22(1), $1-24$.

Mohrenweiser, Jens and Uschi Backes-Gellner (2008). Apprenticeship Training - What for? Investment in Human Capital or Substitute for Cheap 
Labour? Economics of Education Working Paper Series 0017, University of Zurich, Institute for Strategy and Business Economics (ISU).

Mohrenweiser, Jens and Thomas Zwick (2008). Why do Firms Train Apprentices? The Net Cost Puzzle Reconsidered. Economics of Education Working Paper Series 0016, University of Zurich, Institute for Strategy and Business Economics (ISU).

Muehlemann, Samuel, Juerg Schweri, Rainer Winkelmann, and Stefan C. Wolter (2007). An Empirical Analysis of the Decision to Train Apprentices. Labour 21(3), 419-441.

Muehlemann, Samuel and Stefan C. Wolter (2007a). Bildungsqualität, demographischer Wandel, Struktur der Arbeitsmärkte und die Bereitschaft von Unternehmen Lehrstellen anzubieten. Wirtschaftspolitische Blätter 54(1), 135-147.

Muehlemann, Samuel and Stefan C. Wolter (2007b). Regional Effects on Employer-Provided Training: Evidence from Apprenticeship Training in Switzerland. Journal for Labour Market Research 40(2+3), 135-147.

Muehlemann, Samuel, Stefan C. Wolter, Marc Fuhrer, and Adrian Wüest (2007). Lehrlingsausbildung - ökonomisch betrachtet. Beiträge zur Bildungsökonomie, Band 3. Rüegger Verlag.

Noll, Ingeborg, Ursula Beicht, Georg Boll, Wilfried Malcher, and Susanne Wiederhold-Fritz (1983). Nettokosten der betrieblichen Berufsausbildung. Schriften zur Berufsbildungsforschung, Band 23. Berlin: Bundesinstitut für Berufsbildung.

OECD (2004). Employment Outlook. OECD, Paris.

Potterat, Jann (2003). Kosten und Nutzen der Berufsbildung im Jahr 2001 aus der Sicht der Betriebe. Schätzverfahren. Technical report, Neuenburg: Bundesamt für Statistik.

Renfer, Jean-Pierre (2002). Enquête 2001 sur les coûts et l'utilité de la formation des apprentis du point de vue des établissements. Technical report, Neuchâtel: Office fédéral de la statistique. 
Rosenbaum, Paul R. and Donald B. Rubin (1983). The Central Role of the Propensity Score in Observational Studies for Causal Effects. Biometrika $70(1), 41-55$.

Rubin, Donald B. (1974). Estimating Causal Effects of Treatments in Randomized and Nonrandomized Studies. Journal of Eucational Psychology 66, 668-701.

Sachverständigenkommission Kosten und Finanzierung der beruflichen Bildung (1974). Kosten und Finanzierung der ausserschulischen beruflichen Bildung. Bielefeld: Bertelsmann. Abschlussbericht.

Schröder, Helmut, Stefan Schiel, Reiner Gilberg, and Karen Marwinski (2001). Nutzen und Nettokosten der Berufsausbildung: Methodenbericht $z u$ einer repräsentativen Betriebsbefragung. Bonn: infas. Unpublished manuscript.

Schweri, Juerg, Samuel Muehlemann, Yasmina Pescio, Belinda Walter, Stefan C. Wolter, and Lukas Zuercher (2003). Kosten und Nutzen der Lehrlingsausbildung aus der Sicht Schweizer Betriebe, Volume 2 of Beiträge zur Bildungsökonomie. Chur, Zuerich: Ruegger Verlag.

Von Bardeleben, Richard, Ursula Beicht, and Kalman Fehér (1995). Betriebliche Kosten und Nutzen der Ausbildung: repräsentative Ergebnisse aus Industrie, Handel und Handwerk. Bertelsmann, Bielefeld.

Von Bardeleben, Richard, Ursula Beicht, and Kalman Fehér (1997). Was kostet die betriebliche Ausbildung? Fortschreibung der Ergebnisse 1991 auf den Stand 1995. Berichte zur beruflichen Bildung, Heft 210. BIBB, Berlin.

Von Bardeleben, Richard, Ursula Beicht, and Rita Stockmann (1991). Kosten und Nutzen der betrieblichen Berufsausbildung. Forschungsstand, Konzeption, Erhebungsinstrumentarium. Berichte zur beruflichen Bildung, Heft 140. BIBB, Berlin.

Walden, Günter (2007). Short-term and long-term benefits as determinants of the training behaviour of companies. Journal for Labour Market Research $40(2+3), 169-191$. 
Wolter, Stefan C. (2008). Ausbildungskosten und -nutzen und die betriebliche Nachfrage nach Lehrlingen. Perspektiven der Wirtschaftspolitik. forthcoming.

Wolter, Stefan C., Samuel Muehlemann, and Juerg Schweri (2006). Why Some Firms Train Apprentices and Many Others Do Not. German Economic Review 7(3), 249-264.

Wolter, Stefan C. and Juerg Schweri (2002). The Cost and Benefit of Apprenticeship Training: The Swiss Case. Applied Economics Quarterly 48(3-4), 347-67.

Zwick, Thomas (2007). Apprenticeship training in Germany - investment or productivity driven? Journal for Labour Market Research 40(2+3), 193-204. 


\section{A Figures and Tables}

Figure A.1: Histogram of net costs*

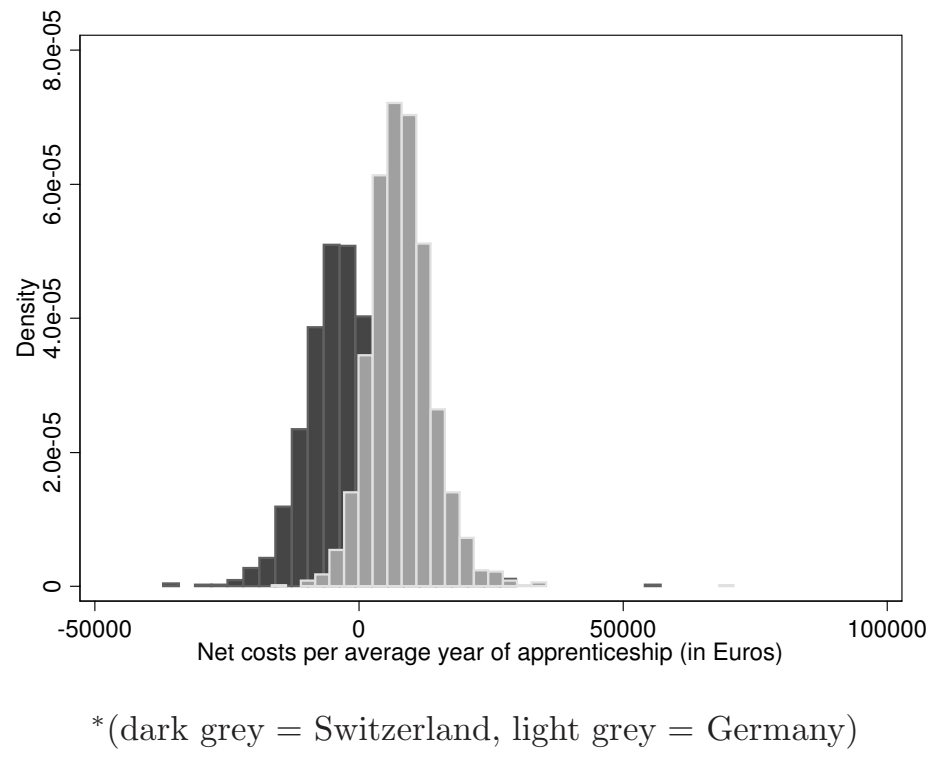


Table A.1: Descriptive statistics, German firms

\begin{tabular}{|c|c|c|c|c|c|}
\hline Variable & Mean & Std. Dev. & Min & Max & Obs \\
\hline Cost per year and per apprentice (in $€)$ & 15536.230 & 5016.783 & 5494 & 81026 & 1825 \\
\hline Benefit per year and per apprentice (in €) & 8008.260 & 3974.080 & 0 & 31894 & 1825 \\
\hline Net cost per year and per apprentice (in€) & 7527.971 & 5564.885 & -16496 & 70987 & 1825 \\
\hline Monthly wage of management (in €) & 3405.067 & 1159.064 & 665 & 15339 & 1825 \\
\hline Monthly wage of full-time training personnel (in €) & 3034.555 & 200.224 & 1841 & 5215 & 1825 \\
\hline Monthly wage of skilled workers (administrative, in $€$ ) & 2011.790 & 453.106 & 767 & 6136 & 1825 \\
\hline Monthly wage of skilled workers (technical/social, in $€$ ) & 2279.005 & 529.185 & 920 & 5113 & 1825 \\
\hline Monthly wage of skilled workers (crafts, in $€$ ) & 1895.212 & 354.695 & 614 & 4090 & 1825 \\
\hline Monthly wage of unskilled workers (no voc. degree in €) & 1482.544 & 324.503 & 491 & 3068 & 1825 \\
\hline Non-wage labor costs (in \%) & 37.252 & 10.737 & 8 & 75 & 1825 \\
\hline Yearly wage costs for apprentices (1st year, in $€$ ) & 7232.920 & 1945.024 & 1071 & 16069 & 1065 \\
\hline Yearly wage costs for apprentices (2nd year in $€$ ) & 8229.483 & 2141.398 & 3675 & 18745 & 1168 \\
\hline Yearly wage costs for apprentices (3rd year in $€)$ & 9191.676 & 2377.987 & 1335 & 20967 & 1063 \\
\hline Vacation days (1st year) & 27.330 & 2.715 & 24 & 35 & 1065 \\
\hline Vacation days (2nd year) & 27.440 & 2.603 & 24 & 35 & 1168 \\
\hline Vacation days (3rd year) & 27.202 & 2.872 & 16 & 35 & 1063 \\
\hline Days in vocational school (1st year) & 66.112 & 17.783 & 39 & 100 & 1065 \\
\hline Days in vocational school (2nd year) & 61.160 & 18.035 & 39 & 100 & 1168 \\
\hline Days in vocational school (3rd year) & 58.173 & 17.982 & 20 & 100 & 1063 \\
\hline Days at the workplace (1st year) & 134.101 & 32.530 & 0 & 187 & 1065 \\
\hline Days at the workplace (2nd year) & 138.129 & 32.086 & 0 & 187 & 1168 \\
\hline Days at the workplace (3rd year) & 142.350 & 31.912 & 0 & 194 & 1063 \\
\hline Share of productive tasks (unskilled, 1st year) & 29.977 & 19.084 & 0 & 100 & 1065 \\
\hline Share of productive tasks (unskilled, 2nd year) & 31.524 & 17.874 & 0 & 100 & 1168 \\
\hline Share of productive tasks (unskilled, 3rd year) & 27.790 & 18.374 & 0 & 95 & 1063 \\
\hline Share of productive tasks (skilled, 1st year) & 13.256 & 15.879 & 0 & 100 & 1065 \\
\hline Share of productive tasks (skilled, 2nd year) & 25.834 & 19.399 & 0 & 100 & 1168 \\
\hline Share of productive tasks (skilled, 3rd year) & 41.238 & 22.937 & 0 & 100 & 1063 \\
\hline Share of tasks with no direct value to firm (1st year) & 56.974 & 23.297 & 10 & 110 & 1065 \\
\hline Share of tasks with no direct value to firm (2nd year) & 42.927 & 19.885 & 7 & 100 & 1168 \\
\hline Share of tasks with no direct value to firm (3rd year) & 31.349 & 17.960 & 5 & 100 & 1063 \\
\hline Relative productivity (1st year) & 30.240 & 15.049 & 5 & 100 & 1065 \\
\hline Relative productivity (2nd year) & 46.713 & 18.278 & 5 & 100 & 1168 \\
\hline Relative productivity (3rd year) & 68.332 & 21.988 & 5 & 100 & 1063 \\
\hline Hours of firm-training per apprentice/week & 5.436 & 2.855 & 0 & 36 & 1825 \\
\hline
\end{tabular}

continued on next page... 
...continued from previous page

\begin{tabular}{|c|c|c|c|c|c|}
\hline Variable & Mean & Std. Dev. & Min & Max & Obs \\
\hline \multicolumn{6}{|l|}{ Firm size: } \\
\hline 1-9 employees & 0.463 & & 0 & 1 & 1825 \\
\hline 10-49 employees & 0.396 & & 0 & 1 & 1825 \\
\hline 50-99 employees & 0.068 & & 0 & 1 & 1825 \\
\hline 100+ employees & 0.073 & & 0 & 1 & 1825 \\
\hline Company training center (yes/no) & 0.015 & & 0 & 1 & 1825 \\
\hline Full-time training personnel (yes/no) & 0.024 & & 0 & 1 & 1825 \\
\hline \multicolumn{6}{|l|}{ Industry: } \\
\hline Agriculture & 0.039 & & 0 & 1 & 1825 \\
\hline Manufacturing & 0.181 & & 0 & 1 & 1825 \\
\hline Energy, water supply & 0.001 & & 0 & 1 & 1825 \\
\hline Construction & 0.105 & & 0 & 1 & 1825 \\
\hline Trade, automotive industry & 0.181 & & 0 & 1 & 1825 \\
\hline Restaurant and hotel & 0.045 & & 0 & 1 & 1825 \\
\hline Transport and communication & 0.020 & & 0 & 1 & 1825 \\
\hline Credit and insurance & 0.022 & & 0 & 1 & 1825 \\
\hline Real estate, IT, R\&D, Services & 0.112 & & 0 & 1 & 1825 \\
\hline Public administration, national security social insurance & 0.024 & & 0 & 1 & 1825 \\
\hline Health and welfare & 0.117 & & 0 & 1 & 1825 \\
\hline Other public or personal services & 0.154 & & 0 & 1 & 1825 \\
\hline \multicolumn{6}{|l|}{ Job categories: } \\
\hline Nature & 0.088 & & 0 & 1 & 1825 \\
\hline Food, restaurant \& hotels, home economics & 0.117 & & 0 & 1 & 1825 \\
\hline Textiles, clothing, hygiene & 0.038 & & 0 & 1 & 1825 \\
\hline Construction & 0.144 & & 0 & 1 & 1825 \\
\hline Manufacturing, craft (technical), IT & 0.097 & & 0 & 1 & 1825 \\
\hline Trade, public administration & 0.364 & & 0 & 1 & 1825 \\
\hline Education, health, social work & 0.135 & & 0 & 1 & 1825 \\
\hline Media, art, social sciences & 0.017 & & 0 & 1 & 1825 \\
\hline
\end{tabular}


Table A.2: Descriptive statistics, Swiss firms

\begin{tabular}{|c|c|c|c|c|c|}
\hline Variable & Mean & Std.Dev. & Min & Max & Obs \\
\hline Cost per year and per apprentice (in $€$ ) & 18130.710 & 7137.790 & 6282 & 66720 & 1471 \\
\hline Benefit per year and per apprentice (in $€$ ) & 19043.530 & 5863.084 & 2748 & 60803 & 1471 \\
\hline Net cost per year and per apprentice (in $€)$ & -912.818 & 8097.626 & -37076 & 57164 & 1471 \\
\hline Monthly wage of management (in €) & 4988.087 & 1601.594 & 1941 & 19406 & 1471 \\
\hline Monthly wage of full-time training personnel (in €) & 3759.393 & 678.115 & 1941 & 9703 & 1471 \\
\hline Monthly wage of skilled workers (administrative, in $€$ ) & 3219.204 & 644.210 & 1294 & 11644 & 1471 \\
\hline Monthly wage of skilled workers (technical/social, in $€$ ) & 3488.207 & 566.926 & 1941 & 7949 & 1471 \\
\hline Monthly wage of skilled workers (crafts, in $€$ ) & 3244.225 & 647.023 & 1294 & 10078 & 1471 \\
\hline Monthly wage of unskilled workers (no voc. degree in $€$ ) & 2351.211 & 406.262 & 1164 & 4164 & 1471 \\
\hline Non-wage labor costs (in \%) & 22.991 & 9.441 & 15 & 50 & 1471 \\
\hline Yearly wage costs for apprentices (1st year, in $€$ ) & 5889.078 & 2175.177 & 1979 & 33188 & 1006 \\
\hline Yearly wage costs for apprentices (2nd year in $€$ ) & 7773.313 & 2489.260 & 2573 & 27779 & 927 \\
\hline Yearly wage costs for apprentices (3rd year in $€$ ) & 10172.420 & 2701.514 & 2492 & 29955 & 886 \\
\hline Vacation days (1st year) & 26.305 & 3.970 & 20 & 35 & 1006 \\
\hline Vacation days (2nd year) & 26.429 & 3.552 & 20 & 35 & 927 \\
\hline Vacation days (3rd year) & 26.797 & 3.753 & 20 & 35 & 886 \\
\hline Days in vocational school & 50.806 & 17.977 & 36 & 188 & 1005 \\
\hline Days in vocational s & 50.839 & 14.690 & 36 & 80 & 927 \\
\hline Days in vocational school (3rd year) & 50.299 & 14.073 & 36 & 80 & 886 \\
\hline Days at the workplace (1st year) & 156.694 & 26.183 & 0 & 194 & 1006 \\
\hline Days at the $\mathrm{y}$ & 156.075 & 21.970 & 16 & 194 & 927 \\
\hline Days at the workplace (3rd year) & 155.673 & 20.851 & 16 & 194 & 886 \\
\hline Share of productive tasks (unskilled, 1 & 50.432 & 20.824 & 0 & 100 & 1006 \\
\hline Share of productive $t$ & 39.398 & 17.817 & 0 & 90 & 927 \\
\hline Share of productive tasks (unskilled, 3rd year) & 28.224 & 17.901 & 0 & 90 & 886 \\
\hline Share of productive tasks (skilled, 1st year) & 28.234 & 20.942 & 0 & 90 & 1006 \\
\hline Share of productive tasks (skilled, 2nd year) & 45.430 & 19.475 & 0 & 100 & 927 \\
\hline Share of productive tasks (skilled, 3rd year) & 58.467 & 19.671 & 0 & 100 & 886 \\
\hline Share of tasks with no direct value to firm (1st year) & 21.334 & 19.154 & 0 & 90 & 1006 \\
\hline Share of tasks with no direct value to firm (2nd year) & 15.172 & 12.322 & 0 & 70 & 927 \\
\hline Share of tasks with no direct value to firm (3rd year) & 13.310 & 11.090 & 0 & 95 & 886 \\
\hline Relative productivity (1st year) & 36.526 & 20.631 & 5 & 100 & 1006 \\
\hline Relative productivity (2nd year) & 53.998 & 18.674 & 5 & 100 & 927 \\
\hline Relative productivity (3rd year) & 74.637 & 17.776 & 8 & 100 & 886 \\
\hline Hours of firm-training per apprentice/week & 6.582 & 4.712 & 0.4 & 20 & 1471 \\
\hline
\end{tabular}

continued on next page... 
...continued from previous page

\begin{tabular}{|c|c|c|c|c|c|}
\hline Variable & Mean & Std.Dev. & Min & $\operatorname{Max}$ & Obs \\
\hline \multicolumn{6}{|l|}{ Firm size: } \\
\hline 1-9 employees & 0.554 & & 0 & 1 & 1471 \\
\hline 10-49 employees & 0.337 & & 0 & 1 & 1471 \\
\hline 50-99 employees & 0.056 & & 0 & 1 & 1471 \\
\hline $100+$ employees & 0.052 & & 0 & 1 & 1471 \\
\hline Company training center (yes/no) & 0.003 & & 0 & 1 & 1471 \\
\hline Full-time training personnel (yes/no) & 0.044 & & 0 & 1 & 1471 \\
\hline \multicolumn{6}{|l|}{ Industry: } \\
\hline Manufacturing & 0.067 & & 0 & 1 & 1471 \\
\hline Energy, water supply & 0.005 & & 0 & 1 & 1471 \\
\hline Construction & 0.172 & & 0 & 1 & 1471 \\
\hline Trade, automotive industry & 0.247 & & 0 & 1 & 1471 \\
\hline Restaurant and hotel & 0.073 & & 0 & 1 & 1471 \\
\hline Transport and communication & 0.034 & & 0 & 1 & 1471 \\
\hline Credit and insurance & 0.044 & & 0 & 1 & 1471 \\
\hline Real estate, IT, R\&D, Services & 0.076 & & 0 & 1 & 1471 \\
\hline Public administration, national security social insurance & 0.079 & & 0 & 1 & 1471 \\
\hline Education & 0.023 & & 0 & 1 & 1471 \\
\hline Health and welfare & 0.112 & & 0 & 1 & 1471 \\
\hline Other public or personal services & 0.069 & & 0 & 1 & 1471 \\
\hline \multicolumn{6}{|l|}{ Job categories: } \\
\hline Nature & 0.037 & & 0 & 1 & 1471 \\
\hline Food, restaurant \& hotels, home economics & 0.158 & & 0 & 1 & 1471 \\
\hline Textiles, clothing, hygiene & 0.058 & & 0 & 1 & 1471 \\
\hline Construction & 0.173 & & 0 & 1 & 1471 \\
\hline Manufacturing, craft (technical), IT & 0.053 & & 0 & 1 & 1471 \\
\hline Trade, public administration & 0.427 & & 0 & 1 & 1471 \\
\hline Education, health, social work & 0.081 & & 0 & 1 & 1471 \\
\hline Media, art, social sciences & 0.013 & & 0 & 1 & 1471 \\
\hline
\end{tabular}


Table A.3: OLS regressions, observed costs and benefits of apprenticeship training

\begin{tabular}{|c|c|c|c|c|c|}
\hline Dep. variable: net costs of training & (1) & $(2)$ & $(3)$ & $(4)$ & $(5)$ \\
\hline \multirow{2}{*}{ German firm } & $8,440.790$ & $8,419.920$ & $8,451.600$ & $8,393.030$ & $8,430.110$ \\
\hline & $(341.242)$ & $(348.124)$ & $(354.404)$ & $(363.585)$ & $(364.929)$ \\
\hline \multirow[t]{2}{*}{ 10-49 employees } & & 199.767 & 220.980 & 54.200 & 19.107 \\
\hline & & $(370.429)$ & $(376.404)$ & $(384.846)$ & $(385.219)$ \\
\hline \multirow[t]{2}{*}{ 50-99 employees } & & 93.905 & 162.186 & -174.137 & -282.606 \\
\hline & & $(595.470)$ & $(614.528)$ & $(606.214)$ & $(605.345)$ \\
\hline \multirow[t]{2}{*}{$100+$ employees } & & 391.134 & 279.571 & -209.029 & -628.357 \\
\hline & & $(415.817)$ & $(437.950)$ & $(473.382)$ & $(492.070)$ \\
\hline \multicolumn{6}{|l|}{ Industry: } \\
\hline \multirow[t]{2}{*}{ Manufacturing } & & & $2,366.010$ & 970.504 & 920.371 \\
\hline & & & $(641.992)$ & $(1,029.978)$ & $(1,031.866)$ \\
\hline \multirow[t]{2}{*}{ Energy, water supply } & & & -316.896 & $-1,590.610$ & $-1,698.850$ \\
\hline & & & $(1,733.012)$ & $(1,858.260)$ & $(1,874.528)$ \\
\hline \multirow[t]{2}{*}{ Construction } & & & $1,880.500$ & 612.369 & 520.503 \\
\hline & & & $(721.028)$ & $(1,194.618)$ & $(1,192.048)$ \\
\hline \multirow[t]{2}{*}{ Trade, automotive industry } & & & $1,477.740$ & 109.714 & 22.190 \\
\hline & & & $(635.753)$ & $(939.205)$ & $(945.611)$ \\
\hline \multirow[t]{2}{*}{ Restaurant and hotel } & & & $2,550.590$ & $2,497.990$ & $2,473.510$ \\
\hline & & & $(894.965)$ & $(1,275.705)$ & $(1,275.058)$ \\
\hline \multirow{2}{*}{ Transport and communication } & & & $3,651.530$ & $1,820.940$ & $1,561.270$ \\
\hline & & & $(1,398.953)$ & $(1,632.160)$ & $(1,657.751)$ \\
\hline \multirow[t]{2}{*}{ Credit and insurance } & & & $3,638.580$ & $2,059.820$ & $1,931.520$ \\
\hline & & & $(1,099.665)$ & $(1,366.846)$ & $(1,370.024)$ \\
\hline \multirow[t]{2}{*}{ Real estate, IT, R\&D, Services } & & & $2,521.980$ & 553.959 & 441.937 \\
\hline & & & $(691.622)$ & $(1,078.059)$ & $(1,078.730)$ \\
\hline \multirow{2}{*}{$\begin{array}{l}\text { Public administration, national } \\
\text { security social insurance }\end{array}$} & & & $1,286.720$ & -278.372 & -378.849 \\
\hline & & & $(887.510)$ & $(1,176.751)$ & $(1,179.366)$ \\
\hline \multirow[t]{2}{*}{ Education } & & & $3,619.290$ & $2,016.980$ & $1,963.060$ \\
\hline & & & $(2,348.171)$ & $(2,486.687)$ & $(2,489.859)$ \\
\hline \multirow[t]{2}{*}{ Health and welfare } & & & $3,246.500$ & $1,967.920$ & $2,088.280$ \\
\hline & & & $(719.882)$ & $(1,362.896)$ & $(1,376.286)$ \\
\hline \multirow[t]{2}{*}{ Other public or personal services } & & & $2,027.510$ & 426.637 & 363.075 \\
\hline & & & $(651.300)$ & $(1,046.911)$ & $(1,047.613)$ \\
\hline \multicolumn{6}{|l|}{ Job categories: } \\
\hline Food, restaurant \& hotels, & & & & 54.141 & -11.463 \\
\hline home economics & & & & $(955.911)$ & $(948.167)$ \\
\hline Textiles, clothing, hygiene & & & & 697.250 & 737.004 \\
\hline & & & & $(1,081.841)$ & $(1,078.933)$ \\
\hline Construction & & & & $1,281.280$ & $1,334.730$ \\
\hline & & & & $(1,050.566)$ & $(1,044.890)$ \\
\hline Manufacturing, craft (technical), IT & & & & $3,165.840$ & $3,139.490$ \\
\hline & & & & $(1,019.026)$ & $(1,020.814)$ \\
\hline Trade, public administration & & & & $1,699.870$ & $1,814.790$ \\
\hline & & & & $(880.167)$ & $(882.828)$ \\
\hline Education, health, social work & & & & $1,387.390$ & $1,233.130$ \\
\hline & & & & $(1,242.508)$ & $(1,252.914)$ \\
\hline Media, art, social sciences & & & & $7,558.310$ & $7,618.330$ \\
\hline & & & & $(1,543.077)$ & $(1,534.213)$ \\
\hline Company training center (yes/no) & & & & & $2,071.430$ \\
\hline & & & & & $(1,733.244)$ \\
\hline Full-time training personnel (yes/no) & & & & & $2,324.600$ \\
\hline Constant & -912818 & -1005090 & م-320509 & -3126110 & $\begin{array}{r}(849.778) \\
-3165940\end{array}$ \\
\hline & $(299.064)$ & $(306.055)$ & $(616.256)$ & $(616.175)$ & $(617.894)$ \\
\hline Observations & 3296 & 3296 & 3296 & 3296 & 3296 \\
\hline $\mathrm{R}^{2}$ & 0.28 & 0.28 & 0.29 & 0.30 & 0.31 \\
\hline
\end{tabular}

Robust standard errors in parentheses 
Table A.4: OLS regressions, simulated costs and benefits for Germany

\begin{tabular}{|c|c|c|c|c|c|}
\hline Dep. variable: net costs of training & $(1)$ & $(2)$ & $(3)$ & $(4)$ & $(5)$ \\
\hline \multirow{2}{*}{ German firm } & $1,846.730$ & $1,910.919$ & $1,584.286$ & $1,518.782$ & $1,494.398$ \\
\hline & $(349.941)$ & $(356.250)$ & $(364.609)$ & $(375.699)$ & $(377.170)$ \\
\hline \multirow[t]{2}{*}{ 10-49 employees } & & -264.654 & -226.310 & -260.562 & -304.467 \\
\hline & & $(379.584)$ & $(380.359)$ & $(390.564)$ & $(389.977)$ \\
\hline \multirow[t]{2}{*}{ 50-99 employees } & & -977.910 & -731.006 & -745.597 & -914.190 \\
\hline & & $(629.499)$ & $(626.952)$ & $(629.718)$ & $(629.618)$ \\
\hline 100+ employees & & $-1,807.712$ & $-1,594.862$ & $-1,663.611$ & $-2,356.822$ \\
\hline \multicolumn{6}{|l|}{ Industry: } \\
\hline Manufacturing & & & $\begin{array}{r}-3,237.304 \\
(622.485)\end{array}$ & $\begin{array}{r}-4,030.593 \\
(987.465)\end{array}$ & $\begin{array}{r}-4,058.566 \\
(1,006.949)\end{array}$ \\
\hline \multirow[t]{2}{*}{ Energy, water supply } & & & $-7,094.034$ & $-7,357.039$ & $-7,406.507$ \\
\hline & & & $(1,711.394)$ & $(1,828.870)$ & $(1,858.995)$ \\
\hline \multirow{2}{*}{ Construction } & & & $-4,455.558$ & $-4,315.206$ & $-4,386.021$ \\
\hline & & & $(732.091)$ & $(1,170.478)$ & $(1,189.389)$ \\
\hline \multirow[t]{2}{*}{ Trade, automotive industry } & & & $-5,203.741$ & $-5,899.106$ & $-5,900.113$ \\
\hline & & & $(640.990)$ & $(888.674)$ & $(909.220)$ \\
\hline \multirow{2}{*}{ Restaurant and hotel } & & & $-2,024.355$ & $-2,601.958$ & $-2,478.782$ \\
\hline & & & $(875.323)$ & $(1,239.204)$ & $(1,250.215)$ \\
\hline \multirow{2}{*}{ Transport and communication } & & & $-2,861.304$ & $-3,567.934$ & $-3,948.424$ \\
\hline & & & $(1,380.569)$ & $(1,586.977)$ & $(1,595.350)$ \\
\hline \multirow[t]{2}{*}{ Credit and insurance } & & & $-3,906.623$ & $-4,436.078$ & $-4,473.206$ \\
\hline & & & $(1,072.804)$ & $(1,317.263)$ & $(1,333.070)$ \\
\hline \multirow[t]{2}{*}{ Real estate, IT, R\&D, Services } & & & $-4,044.649$ & $-4,796.523$ & $-4,912.206$ \\
\hline & & & $(674.649)$ & $(1,038.439)$ & $(1,051.969)$ \\
\hline \multirow{2}{*}{$\begin{array}{l}\text { Public administration, national } \\
\text { security social insurance }\end{array}$} & & & $-6,022.158$ & $-6,570.551$ & $-6,602.394$ \\
\hline & & & $(886.400)$ & $(1,143.894)$ & $(1,159.374)$ \\
\hline \multirow[t]{2}{*}{ Education } & & & $-2,603.327$ & $-3,087.283$ & $-3,170.455$ \\
\hline & & & $(2,342.277)$ & $(2,476.487)$ & $(2,489.077)$ \\
\hline \multirow[t]{2}{*}{ Health and welfare } & & & $-2,169.132$ & $-4,187.130$ & $-3,587.140$ \\
\hline & & & $(732.651)$ & $(1,413.714)$ & $(1,377.367)$ \\
\hline \multirow[t]{2}{*}{ Other public or personal services } & & & $-4,725.082$ & $-5,739.618$ & $-5,695.255$ \\
\hline & & & $(648.707)$ & $(1,028.784)$ & $(1,051.281)$ \\
\hline \multicolumn{6}{|l|}{ Job categories: } \\
\hline \multirow{2}{*}{$\begin{array}{l}\text { Food, restaurant \& hotels, } \\
\text { home economics }\end{array}$} & & & & 585.880 & 448.536 \\
\hline & & & & $(930.652)$ & $(929.231)$ \\
\hline Textiles, clothing, hygiene & & & & 650.378 & 623.867 \\
\hline & & & & $(1,067.551)$ & $(1,075.845)$ \\
\hline Construction & & & & -261.216 & -257.672 \\
\hline & & & & $(1,017.339)$ & $(1,021.753)$ \\
\hline Manufacturing, craft (technical), IT & & & & $1,674.650$ & $1,455.780$ \\
\hline & & & & $(1,007.161)$ & $(1,009.980)$ \\
\hline Trade, public administration & & & & 526.824 & 627.074 \\
\hline & & & & $(846.437)$ & $(852.247)$ \\
\hline Education, health, social work & & & & $2,228.979$ & $1,595.842$ \\
\hline & & & & $(1,333.208)$ & $(1,268.695)$ \\
\hline Media, art, social sciences & & & & $6,962.142$ & $7,004.361$ \\
\hline & & & & $(1,516.964)$ & $(1,515.669)$ \\
\hline Company training center (yes/no) & & & & & $8,567.197$ \\
\hline & & & & & $(1,539.037)$ \\
\hline Full-time training personnel (yes/no) & & & & & $1,525.095$ \\
\hline & & & & & $(919.606)$ \\
\hline Constant & -912.818 & -673.885 & $3,414.702$ & $3,461.746$ & $3,436.260$ \\
\hline & $(299.064)$ & $(309.378)$ & $(608.711)$ & $(615.555)$ & $(626.962)$ \\
\hline Observations & 3296 & 3296 & 3296 & 3296 & 3296 \\
\hline $\mathrm{R}^{2}$ & 0.02 & 0.02 & 0.05 & 0.07 & 0.09 \\
\hline
\end{tabular}

Robust standard errors in parentheses 
Table A.5: OLS regressions, simulated costs and benefits for Switzerland

\begin{tabular}{|c|c|c|c|c|c|}
\hline Dep. variable: net costs of training & (1) & $(2)$ & $(3)$ & $(4)$ & $(5)$ \\
\hline \multirow{2}{*}{ German firm } & -390.140 & -421.420 & -160.860 & -180.680 & -146.190 \\
\hline & $(259.280)$ & $(265.053)$ & $(269.393)$ & $(269.878)$ & $(269.847)$ \\
\hline \multirow[t]{2}{*}{ 10-49 employees } & & 166.783 & 211.124 & -84.870 & -119.006 \\
\hline & & $(291.019)$ & $(292.243)$ & $(289.056)$ & $(288.966)$ \\
\hline \multirow[t]{2}{*}{ 50-99 employees } & & 117.168 & -6.093 & -612.068 & -718.314 \\
\hline & & $(495.079)$ & $(502.888)$ & $(488.326)$ & $(486.070)$ \\
\hline \multirow[t]{2}{*}{ 100+ employees } & & 971.863 & 488.801 & -344.109 & -755.769 \\
\hline & & $(387.646)$ & $(391.754)$ & $(414.358)$ & $(435.082)$ \\
\hline \multicolumn{6}{|l|}{ Industry: } \\
\hline \multirow[t]{2}{*}{ Manufacturing } & & & $2,350.660$ & 775.528 & 727.540 \\
\hline & & & (619.503) & $(902.154)$ & $(910.658)$ \\
\hline \multirow[t]{2}{*}{ Energy, water supply } & & & $4,400.846$ & $2,962.614$ & $2,859.256$ \\
\hline & & & $(1,128.537)$ & $(1,254.483)$ & $(1,259.600)$ \\
\hline \multirow{2}{*}{ Construction } & & & $1,716.632$ & 496.866 & 408.493 \\
\hline & & & $(630.694)$ & $(1,011.844)$ & $(1,022.267)$ \\
\hline \multirow[t]{2}{*}{ Trade, automotive industry } & & & $1,696.115$ & -12.274 & -94.984 \\
\hline & & & $(611.050)$ & $(840.415)$ & $(851.101)$ \\
\hline \multirow[t]{2}{*}{ Restaurant and hotel } & & & 504.710 & 240.190 & 219.820 \\
\hline & & & $(728.777)$ & $(1,022.957)$ & $(1,026.416)$ \\
\hline \multirow{2}{*}{ Transport and communication } & & & $3,111.870$ & 776.030 & 522.210 \\
\hline & & & $(1,086.998)$ & $(1,280.718)$ & $(1,308.864)$ \\
\hline \multirow[t]{2}{*}{ Credit and insurance } & & & $6,317.404$ & $4,227.744$ & $4,105.709$ \\
\hline & & & $(807.537)$ & $(1,052.044)$ & $(1,060.940)$ \\
\hline \multirow[t]{2}{*}{ Real estate, IT, R\&D, Services } & & & $2,183.327$ & -169.936 & -278.355 \\
\hline & & & $(634.284)$ & $(929.415)$ & $(936.987)$ \\
\hline \multirow{2}{*}{$\begin{array}{l}\text { Public administration, national } \\
\text { security social insurance }\end{array}$} & & & $4,175.946$ & $2,195.305$ & $2,099.668$ \\
\hline & & & $(661.890)$ & $(916.258)$ & (923.419) \\
\hline \multirow[t]{2}{*}{ Education } & & & $4,673.543$ & $2,602.036$ & $2,549.236$ \\
\hline & & & $(1,683.421)$ & $(1,786.396)$ & $(1,789.680)$ \\
\hline \multirow[t]{2}{*}{ Health and welfare } & & & $3,225.701$ & $2,709.745$ & $2,836.877$ \\
\hline & & & $(688.774)$ & $(1,163.612)$ & $(1,173.615)$ \\
\hline \multirow[t]{2}{*}{ Other public or personal services } & & & $1,912.339$ & 369.940 & 310.883 \\
\hline & & & $(634.343)$ & $(939.151)$ & $(944.165)$ \\
\hline \multicolumn{6}{|l|}{ Job categories: } \\
\hline Food, restaurant \& hotels, & & & & 316.100 & 251.050 \\
\hline home economics & & & & $(756.271)$ & $(758.633)$ \\
\hline Textiles, clothing, hygiene & & & & 105.724 & 142.688 \\
\hline & & & & $(902.087)$ & $(903.658)$ \\
\hline Construction & & & & $1,175.710$ & $1,226.291$ \\
\hline & & & & $(837.144)$ & $(846.806)$ \\
\hline Manufacturing, craft (technical), IT & & & & $3,572.716$ & $3,542.930$ \\
\hline & & & & $(818.459)$ & $(827.119)$ \\
\hline Trade, public administration & & & & $2,320.359$ & $2,431.174$ \\
\hline & & & & $(714.681)$ & $(724.757)$ \\
\hline Education, health, social work & & & & 477.830 & 317.940 \\
\hline & & & & $(1,050.409)$ & $(1,057.123)$ \\
\hline Media, art, social sciences & & & & $6,182.341$ & $6,239.991$ \\
\hline & & & & $(1,049.710)$ & $(1,043.819)$ \\
\hline Company training center (yes/no) & & & & & $2,148.577$ \\
\hline & & & & & $(1,710.082)$ \\
\hline Full-time training personnel (yes/no) & & & & & $2,230.240$ \\
\hline & & & & & $(813.046)$ \\
\hline Constant & $7,918.108$ & $7,804.317$ & $5,416.413$ & $5,515.731$ & $5,477.531$ \\
\hline & $(200.547)$ & $(215.430)$ & $(576.043)$ & $(573.453)$ & $(574.691)$ \\
\hline Observations & 3296 & 3296 & 3296 & 3296 & 3296 \\
\hline $\mathrm{R}^{2}$ & 0.00 & 0.00 & 0.05 & 0.08 & 0.09 \\
\hline
\end{tabular}

Robust standard errors in parentheses 
Table A.6: ATT and ATC on wages.

\begin{tabular}{lrr}
\hline Variable & ATT & ATC \\
\hline Monthly wage of management & -1806.713 & -1938.711 \\
& $(109.053)$ & $(116.864)$ \\
Monthly wage of full-time training personnel & -841.785 & -1014.987 \\
& $(43.226)$ & $(53.106)$ \\
Monthly wage of skilled workers (administrative) & -1247.164 & -1347.959 \\
Monthly wage of skilled workers (technical/social) & -1292.403 & -1332.211 \\
& $(45.660)$ & $(50.265)$ \\
Monthly wage of skilled workers (crafts) & -1370.123 & -1437.765 \\
& $(36.666)$ & $(42.130)$ \\
Monthly wage of unskilled workers (no voc. degree) & -921.304 & -934.100 \\
& $(29.359)$ & $(33.261)$ \\
Non-wage labor costs (in \%) & 14.258 & 14.496 \\
& $(0.851)$ & $(0.950)$ \\
Yearly wage costs for apprentices (1st year) & 1817.070 & 1903.519 \\
Yearly wage costs for apprentices (2nd year) & $(163.334)$ & $(230.941)$ \\
Yearly wage costs for apprentices (3rd year) & 812.026 & 1216.873 \\
& $(229.600)$ & $(229.385)$ \\
\hline
\end{tabular}

Standard errors in parentheses 
Table A.7: ATT and ATC on parameters related to the VET-system

\begin{tabular}{lrr}
\hline Variable & ATT & ATC \\
\hline Vacation days (1st year) & 1.201 & 0.914 \\
& $(0.248)$ & $(0.333)$ \\
Vacation days (2nd year) & 0.894 & 1.242 \\
& $(0.281)$ & $(0.286)$ \\
Vacation days (3rd year) & 0.712 & 0.950 \\
& $(0.318)$ & $(0.269)$ \\
Days in vocational school (1st year) & 11.528 & 11.947 \\
Days in vocational school (2nd year) & $(1.304)$ & $(1.758)$ \\
& 8.463 & 6.770 \\
Days in vocational school (3rd year) & $(1.454)$ & $(1.513)$ \\
& 7.283 & 4.112 \\
Internal courses (hours/year, 1st year) & $(1.698)$ & $(1.423)$ \\
Internal courses (hours/year, 2nd year) & 12.310 & 7.711 \\
Internal courses (hours/year, 3rd year) & $(4.264)$ & $(4.954)$ \\
Internships in other establishments (1st year) & 2.337 & 3.233 \\
Internships in other establishments (2nd year) & $(5.664)$ & $(4.695)$ \\
Internships in other establishments (3rd year) & 3.479 & 2.191 \\
Sick days (1st year) & $(5.632)$ & $(4.052)$ \\
Sick days (2nd year) & 2.280 & 0.826 \\
External courses (days, 3rd year) & $(1.036)$ & $(1.259)$ \\
& 1.967 & 1.874 \\
Stans (3rd year) & $(1.250)$ & $(1.449)$ \\
& 0.072 & 0.739 \\
& $(1.258)$ & $(1.190)$ \\
& 2.848 & 2.623 \\
& $(0.451)$ & $(0.587)$ \\
& 1.725 & 1.938 \\
& $(0.644)$ & $(0.683)$ \\
& 2.044 & 1.841 \\
& $(0.634)$ & $(0.579)$ \\
& 1.032 & 1.187 \\
& $(1.655)$ & $(1.829)$ \\
& 4.051 & 2.481 \\
& $1.542)$ & $(1.526)$ \\
& 5.326 \\
& & \\
& $1.975)$ & \\
& & \\
& &
\end{tabular}

Standard errors in parentheses 
Table A.8: ATT and ATC on task-allocation

\begin{tabular}{lrr}
\hline Variable & ATT & ATC \\
\hline Share of productive tasks normally carried & -21.838 & -22.916 \\
out by workers without voc. degree (1st year) & $(1.522)$ & $(1.949)$ \\
& & \\
Share of productive tasks normally carried & -8.375 & -7.828 \\
out by workers without voc. degree (2nd year) & $(1.663)$ & $(1.676)$ \\
& & \\
Share of productive tasks normally carried & -4.770 & -1.544 \\
out by workers without voc. degree (3rd year) & $(1.975)$ & $(1.588)$ \\
& & \\
Share of productive tasks normally carried & -14.778 & -14.652 \\
out by workers with voc. degree (1st year) & $(1.426)$ & $(1.778)$ \\
& & \\
& -19.182 & -20.703 \\
Share of productive tasks normally carried & $(1.790)$ & $(1.818)$ \\
out by workers with voc. degree (2nd year) & & \\
& -12.339 & -17.298 \\
Share of productive tasks normally carried & $(2.457)$ & $(1.907)$ \\
out by workers with voc. degree (3rd year) & & \\
& 36.751 & 37.629 \\
Share of productive tasks normally carried & $(1.523)$ & $(1.998)$ \\
out by workers with voc. degree (1st year) & & \\
& 27.800 & 28.696 \\
Share of productive tasks normally carried & $(1.567)$ & $(1.489)$ \\
out by workers with voc. degree (2nd year) & & \\
Share of productive tasks normally carried & 17.416 & 19.196 \\
out by workers with voc. degree (3rd year) & $(1.742)$ & $(1.405)$ \\
\hline Stan & &
\end{tabular}

Standard errors in parentheses 